\title{
Experimental Water Quality Analysis from the Use of High Sulfuric Fly Ash as Base Course Material for Road Building
}

\author{
Nguyen Viet Duc \\ Faculty of Civil Engineering \\ Thuyloi University \\ Hanoi, Vietnam \\ ducnv@tlu.edu.vn
}

\begin{abstract}
Water quality directly influences human life. Drinking water contamination can result in severe health problems. This paper deals with the analysis of water specimens from submergence of material containing high sulfuric fly ash as base course material for road building. The specimens were obtained from real road testing. Results showed that for the material that used fly ash and chemical admixture, water quality was suitable for drinking in accordance with the standard parameters prescribed by the Vietnam Ministry of Health, while for the material that used the same fly ash without chemical admixture, the total arsenic content was eight times higher than that of the former. Thus, if one desires to utilize fly ash with high sulfur as base course material for road building, it needs to be used in combination with appropriate chemical admixture, so that it would not affect ground water quality.
\end{abstract}

Keywords-fly ash with high sulfur; base course material; real road testing; water quality analysis; chemical admixture

\section{INTRODUCTION}

Electricity consumption is growing nowadays especially in developing countries like Vietnam along with economy transformation [1]. According to the recent forecasting consumption, Vietnam electricity system will need more than $500 \mathrm{GWh}$ by the year 2030 [2-5]. The latest master plan for the power system of the country revealed that a half of that figure will be supplied by coal-fired thermal power plants [6]. Along with that, there will be million tons of fly ash from these plants dumped to the environment. Apart from the ordinary fly ash, there will be also a vast amount of fly ash with high sulfuric content, which can be used for concrete or cement if it is properly treated [7-10]. In order to improve the environmental acceptability and reduce the construction cost of the deep mixing method, the replacement of ordinary Portland cement by supplementary cementing materials such as ordinary fly ash has been recently involved into road building [11-16]. When mixed with lime and water, fly ash forms a compound similar to cement. When used with cement, fly ash improves strength and durability, particularly where the locally available soil is poor $[17,18]$. Fly ash with high sulfur has been attempted to be

Corresponding author: Nguyen Viet Duc, Thuyloi University,

175 Tay Son, Dong Da, Hanoi, Vietnam used as base course material for road building [19-21]. This type of fly ash improved the physical and mechanical properties of soil similarly to the ordinary fly ash. However, when it rains, water falling on the road diffuses into soil along with other materials used for road building, which might be detrimental to ground water quality, and ultimately would affect public health [22-24]. The aim of this paper is to evaluate water, which was used for submerging the specimens up to saturated condition. The specimens were obtained from a road which was built by using fly ash with high sulfur as base coarse material. Water quality was evaluated in accordance with the standards prescribed by the Vietnam Ministry of Health [25].

\section{WATER SAMPLE COLLECTION}

In this study, a real road building test was performed. Onekilometer rural road in Ward Huu Lung, Lang Son Province, Vietnam was taken into consideration. The road was divided into four segments of 250 meters each, which served for testing four different materials, as shown in Table I. The first material was local soil with 5\% cement and 5\% fine crushed stone. The second and third ones were mixes with $9 \%$ and $5 \%$ high sulfur fly ash and 5\% cement. In the third mix, chemical admixture was also used with the amount of 5\% cement weight. Fly ash with high sulfur was not added into the fourth mix, which used only $5 \%$ cement and admixture.

TABLE I. MATERIALS USED FOR THE ROAD BUILDING TEST

\begin{tabular}{|c|c|c|c|c|}
\hline & Material 1 & Material 2 & Material 3 & Material 4 \\
\hline Local soil & 1 & 1 & 1 & 1 \\
\hline Cement PC40 & 0.05 & 0.05 & 0.05 & 0.05 \\
\hline Fine crushed stone & 0.05 & - & - & - \\
\hline Fly ash with high sulfur & - & 0.09 & 0.05 & - \\
\hline Chemical admixture & - & - & 0.0025 & 0.0025 \\
\hline
\end{tabular}

All road building tests were carried out by equipment provided from the VIETRACO JSC such as SAKAI ${ }^{\circledR}$ stabilizer machine, rollers, rammers, etc. At first, the optimum moisture content of the local soil was determined, depending upon the water content that might be added to the soil. For the first road segment (Material 1), after the placement of fine 
crushed stone, cement was dispersed with a thin layer, as it can be seen in Figure 1. For the rest road segments (Material 2, Material 4) cement and/or fly ash with high sulfur were placed above the local soil. After the placing of raw materials (fine crushed stone, cement, and/or fly ash), the stabilizer machine came in and blended local soil and raw materials together. Chemical admixture and water were added during the mixing process (Figure 2). Finally, a rammer and a roller came in to press and vibrate the composite material until its surface became plane and dense.

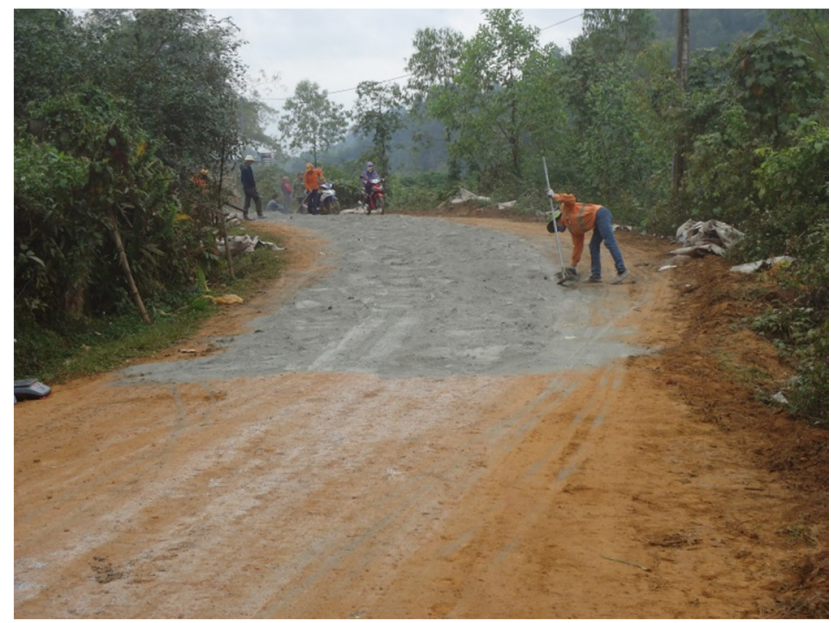

Fig. 1. Cement and/or fly ash placement on the road before mixing with local soil underneath

At 28 days, specimen extraction was carried out from all the road segments by a hand-held coring machine. The specimens from those segments are shown in Figure 3. After extraction from the field, all specimens were moved to the laboratory for further study. The specimens were submerged into distilled water for 72 hours until reaching a saturated condition, as it can be seen in Figure 4. After that, water sample collection was conducted, as shown in Figure 5. Water quality was estimated following the directives of [25] (Table II).

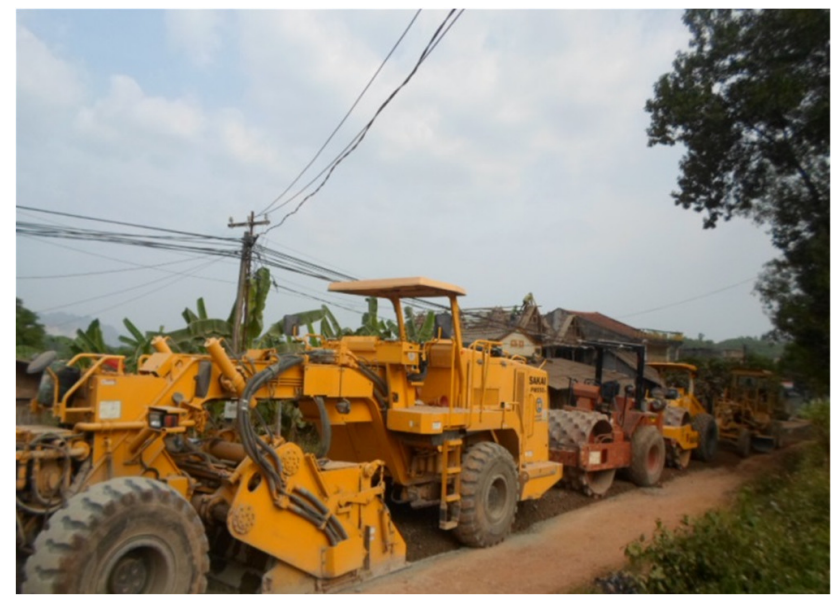

Fig. 2. Picture of on site equipment during the test

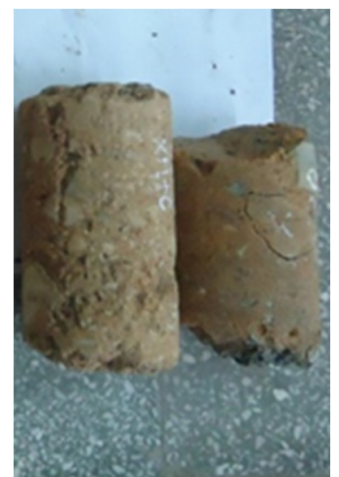

(a)

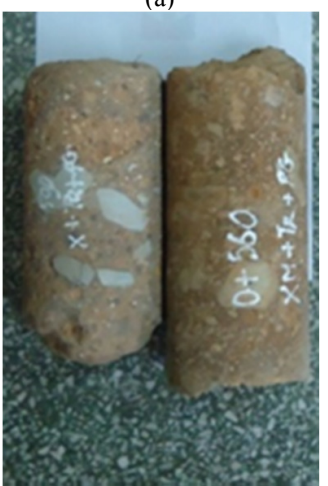

(c)

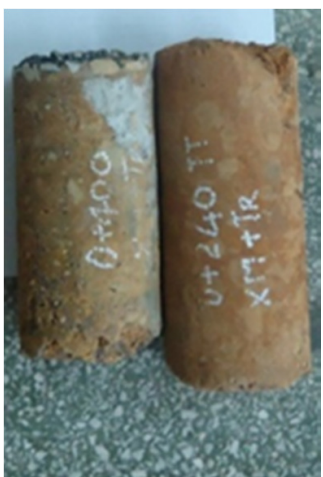

(b)

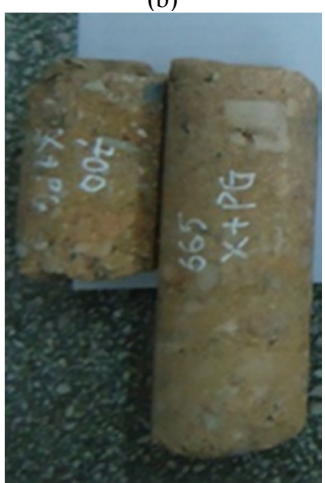

(d)
Fig. 3. Sample extraction from the four road segments: a) Material 1, b) Material 2, c) Material 3, d) Material 4

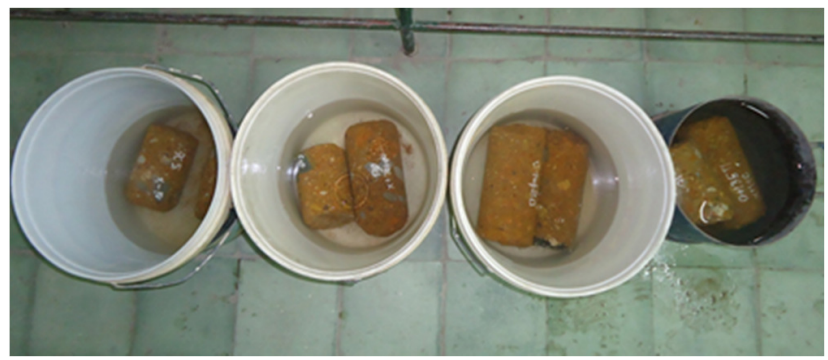

Fig. 4. Specimen submergence into distilled water

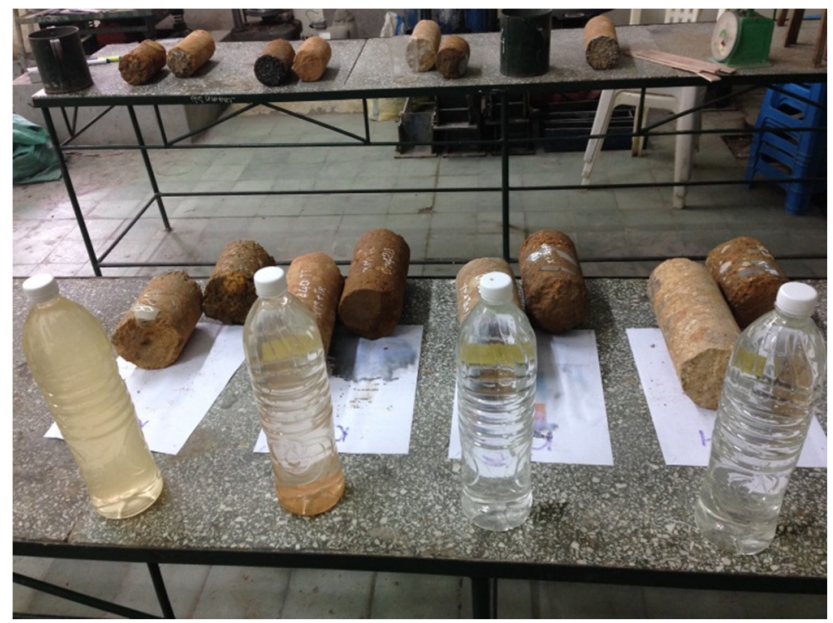

Fig. 5. Water sample collection used for analysis 
TABLE II. STANDARD VALUES OF POTABLE WATER [8]

\begin{tabular}{|c|c|c|}
\hline Parameters & Units & Standard value \\
\hline pH indicator & - & $6.5-8.5$ \\
\hline Ammonium content & $\mathrm{mg} / \mathrm{l}$ & $\leq 3$ \\
\hline Total arsenic content & $\mathrm{mg} / \mathrm{l}$ & $\leq 0.01$ \\
\hline Chloride content & $\mathrm{mg} / \mathrm{l}$ & $\leq 300$ \\
\hline Total iron content & $\mathrm{mg} / 1$ & $\leq 0.3$ \\
\hline Lead content & $\mathrm{mg} / \mathrm{l}$ & $\leq 0.01$ \\
\hline Total mercury content & $\mathrm{mg} / 1$ & $\leq 0.001$ \\
\hline Total manganese content & $\mathrm{mg} / \mathrm{l}$ & $\leq 0.3$ \\
\hline Nitrite content & $\mathrm{mg} / \mathrm{l}$ & $\leq 3$ \\
\hline E coli and/or coliform bacteria & - & No bacteria $/ 100 \mathrm{ml}$ \\
\hline
\end{tabular}

\section{RESULTS AND DISCUSSION}

The results of water quality analysis are presented in Table III. It can be seen that the $\mathrm{pH}$ indicator of all samples, including the ones with fly ash (Materials 2-3), complies with the standard potable water values in Table II. Regarding ammonium content, the similar outcome is also observed. Total arsenic content from all samples is within the standard values except the one of Material 2. Chloride content from the water of Material 2 is the highest, however all of them are within standard values. The other parameters such as total iron content, lead content, total mercury content, total manganese content and nitrite content from the water of all samples are in compliance with the standard values. Eventually, no E coli and/or coliform bacteria were found in the water of all materials.

TABLE III. WATER QUALITY ANALYSIS RESULTS

\begin{tabular}{|c|c|c|c|c|c|}
\hline \multirow{2}{*}{ Parameters } & \multirow{2}{*}{ Units } & \multicolumn{4}{|c|}{ Material } \\
\cline { 3 - 6 } & & $\mathbf{1}$ & $\mathbf{2}$ & $\mathbf{3}$ & $\mathbf{4}$ \\
\hline pH indicator & - & 7.93 & 7.88 & 7.94 & 8.27 \\
\hline Ammonium content & $\mathrm{mg} / \mathrm{l}$ & 2.99 & 2.79 & 2.59 & 2.47 \\
\hline Total arsenic content & $\mathrm{mg} / \mathrm{l}$ & 0.006 & 0.08 & 0.009 & 0.009 \\
\hline Chloride content & $\mathrm{mg} / 1$ & 5.68 & 6.75 & 5.68 & 6.04 \\
\hline Total iron content & $\mathrm{mg} / 1$ & 0.262 & 0.21 & 0.08 & 0.08 \\
\hline Lead content & $\mathrm{mg} / 1$ & 0.009 & 0.009 & 0.008 & 0.001 \\
\hline Total mercury content & $\mathrm{mg} / 1$ & 0.001 & 0.001 & 0.001 & 0.001 \\
\hline Total manganese content & $\mathrm{mg} / 1$ & 0.16 & 0.074 & 0.0016 & 0.0043 \\
\hline Nitrite content & $\mathrm{mg} / 1$ & 0.545 & 0.593 & 0.591 & 0.583 \\
\hline E coli and/or coliform bacteria & - & No & No & No & No \\
\hline
\end{tabular}

It is noteworthy that due to the total arsenic content from the water of Material 2, which is about eight times higher than that of the rest, only this material that used fly ash with high sulfur would not be applied for road building, because arsenic is very harmful [22]. On the other hand, Material 3 also involves fly ash with high sulfur, but the difference here is the use of proper chemical admixture. According to the supplier, this admixture is able to be dispersed around heavy metals in the specimen and prevent them from being emitted to water.

\section{CONCLUSION}

Although fly ash with high sulfur can improve physical and mechanical properties of road building soil, the environmental issue related to the use of this industrial waste must be examined. Water from specimen submergence of the material that used fly ash with high sulfur for road building was analyzed in this study. The main conclusions of this study are:
- Water derived from specimen submergence of all materials in this study complies with the quality parameters prescribed by the Vietnam Ministry of Health, except for water sampled from the material that used fly ash with high sulfur.

- For the material that used the same fly ash and chemical admixture, the water quality was suitable for drinking. The admixture seemed to prevent metallic substances, which are very harmful for human health, from being emitted to water during submergence.

- Thus, if one desires to utilize high sulfur fly ash for road building, it is recommended to be used in combination with the appropriate chemical admixture, so that it would not affect ground water quality.

\section{ACKNOWLEDGMENT}

The author would like to express his gratitude to Mr. Dao Minh, CEO of VIETRACO JSC for his help and contribution to the present paper.

\section{REFERENCES}

[1] http://data.worldbank.org/country/vietnam

[2] General Statistics Office of Vietnam, Master Investigation on Population and Households, General Statistics Office of Vietnam, 2009

[3] General Statistics Office of Vietnam, Master Investigation on Population and Households, General Statistics Office of Vietnam, 2014

[4] General Statistics Office of Vietnam, United Nations Fund for Population Activities, Vietnam Population Projection 2014-2049, Vietnam News Agency Publishing House, 2016

[5] V. H. M. Nguyen, C. V. Vo, K. T. P. Nguyen, B. T. T Phan, "Forecast on 2030 vietnam elecitricity consumption", Engineering, Technology \& Applied Science Research, Vol. 8, No. 3, pp. 2869-2874, 2018

[6] Institute of Energy, EVN, Revised Power Master Plan No. VII, Ministry of Industry and Trade, 2015

[7] L. D. Luong, D. V. Nguyen, H. T. Luu, H. V. Le, T. M. Nguyen, "Study on fluidized bed combusion fly ash with high sulfur from Cao Ngan coal-fired thermal power plant for production of construction materials", Vietnamese Journal of Science and Technology, Vol. 1-2, No. 6, pp. 816,2010

[8] C. S. Shon, D. Saylak, S. Mishra, "Evaluation of manufactured fluidized bed combustion ash aggregate as road base coarse materials", World of Coal Ash Conference, Denver, USA, May 9-12, 2011

[9] D. Gazdic, M. Fridrichova, K. Kulisek, L. Vehovska, "The potential use of the FBC ash for the preparation of blended cements", Procedia Engineering, Vol. 180, pp. 1298-1305, 2017

[10] X. M. Xie, L. Guo, "Study on preparation and properties of fly ash concrete with high sulfur and high-calcium fly", 2nd IEEE International Conference on Information Management and Engineering, Chengdu, China, April 16-18, 2010

[11] H. Afrin, "A Review on Different Types Soil Stabilization Techniques", International Journal of Transportation Engineering and Technology, Vol. 3, No. 2, pp. 19-24, 2017

[12] B. R. Phanikumar, S. S. Radhey, "Effect of fly ash on Engineering properties of Expansive Soil" Journal of Geotechnical and Geoenvironmental Engineering, Vol. 130, No 7, pp. 764-767, 2004

[13] A. Hilmi, M. Aysen, "Analyses and design of a stabilized Fly ash as Pavement base material", Fuel, Vol. 85, No. 16, pp. 2359-2370, 2006

[14] S. Karthik, E. K. Ashok, P. Gowtham, G. Elango, D. Gokul, S. Thangaraj, "Soil stabilization by using fly ash", Journal of Mechanical and Civil Engineering, Vol. 10, No. 6, pp. 20-26, 2014 
[15] J. Vestin, M. Arm, D. Nordmark, A. Lagerkvist, P. Hallgren, B. Lind, "Fly ash as a road construction materials", WASCON 2012 Conference proceedings, ISCOWA and SGI, 2012

[16] A. Mouratidis, "Stabilization of pavements with fly-ash", Conference on Use of Industrial Byproducts in Road Construction, Thessaloniki, Greece, 2004

[17] N. S. Pandian, K. C. Krishna, B. Leelavathamma, "Effect of Fly Ash on the CBR Behavior of Soils", Indian Geotechnical Conference, Allahabad, India, 2002

[18] M. R. Hall, K. B. Najim, P. Keikhaei Dehdezi, "Soil stabilization and earth construction: materials, properties and techniques", in: Modern Earth Buildings, pp. 222-255, Woodhead Publishing Limited, 2012

[19] V. D. Nguyen, "Cementitious materials for stabilizing clayey soils in road building", International Journal of Engineering and Technology, Vol. 7, No. 4, pp. 6105-6108, 2018

[20] American Coal Ash Association, Fly Ash Facts for Fighway Engineers, Federal Highway Administration, 2003

[21] S. Kolias, A. Karahalios, "Analytical design of pavements incorporating a capping layer of stabilized soil with high calcium fly ash and or cement", $1^{\text {st }}$ Conference for the Utilization of Industrial by Products in Building Construction, Thessaloniki, Greece, 2005

[22] A. N. Laghari, Z. A. Siyal, D. K. Bangwar, M. A. Soomro, G. Walasai, F. A. Shaikh, "Grounwater quality analysis for human consumption: A case study of Sukkur City, Pakistan", Engineering, Technology \& Applied Science Research, Vol. 8, No. 1, pp. 2616-2620, 2018

[23] S. V. S. Prasanth, N. S. Magesh, K. V. Jitheshlal, "Evaluation of groundwater quality and its suitability for drinking and agricultutal use in the coastal stretch of Alappuzha Distrist, Kerala, India”, Applied Water Science, Vol. 2, No. 3, pp. 165-175, 2012

[24] A. Olusola, O. Adeyeye, O. Durowoju, "Groundwater: Quality levels and human exposure, SW Nigeria", Journal of Environmental Geography, Vol. 10, No. 1-2, pp. 23-29, 2017

[25] Vietnam Ministry of Health, National Technical Regulation on Domestic Water Quality, 2009 